\title{
Sulfonated PEI membrane with GPTMS-TiO 2 as a filler for potential direct methanol fuel cell (DMFC) applications
}

\author{
Eka Cahya Muliawati a, b, Ahmad Fauzi Ismail b, c, Juhana Jaafar b, c, ${ }^{\star}$, Nurul Widiastuti a, ${ }^{\star}$, Mardi

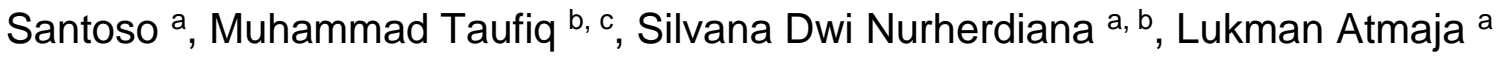 \\ a Department of Chemistry, Faculty of Mathematics and Natural Sciences, Institute of Teknologi Sepuluh Nopember, 60111 Surabaya, Indonesia \\ b Advanced Membrane Technology Research Centre (AMTEC), Universiti Teknologi Malaysia,, 81310 UTM Johor Bahru, Johor, Malaysia \\ ${ }^{c}$ Faculty of Petroleum and Renewable Energy Engineering, Universiti Teknologi Malaysia, 81310 UTM Skudai, Johor Bahru, Malaysia \\ * Corresponding author: juhana@petroleum.utm.my,nurul_widiastuti@chem.its.ac.id
}

\section{Article history}

Received 5 May 2018

Revised 1 June 2018

Accepted 2 July 2018

Published Online 25 August 2019

\begin{abstract}
This study addresses the effect of 3-Glycidyloxy propyl trimethoxy silane (GPTMS)-modified titanium dioxide $\left(\mathrm{TiO}_{2}\right)$ which composited sulfonated polyetherimide (SPEI) as a proton exchanger on direct methanol fuel cell (DMFC). The membrane fabrication was mainly based on phase-inversion method after GPTMS- $\mathrm{TiO}_{2}$ and SPEI were prepared separately. Fourier transform infrared spectroscopy (FTIR), thermogravimetric analysis (TGA), scanning electronic microscopy (SEM), ion exchange capacity (IEC), proton conductivity, water uptake, methanol permeability, and mechanical properties were utilized to characterize and measure their physical and thermal stability. As the result, high water uptake and IEC performance were achieved using the fabricated membrane. Lower methanol permeability was observed compared to Nafion 117 membranes. The membrane performance showed improvement using $20 \mathrm{wt} \% \mathrm{SPEI}$ and $5 \mathrm{wt} \% \mathrm{TiO}_{2}-5 \mathrm{wt} \%$ GPTMS with an optimum result of 3 times lower in terms of methanol uptake and methanol permeability with proton conductivity of $21 \mathrm{mS} . \mathrm{cm}^{-1}$ than the remaining membranes and Nafion. Thus, the obtained results of SPEI/TiO ${ }_{2}-G^{-G T M S}$ can be promoted as a novel polymeric membrane for DMFC.
\end{abstract}

Keywords: Sulfonated polyetherimide, titanium dioxide, blend membrane, direct methanol fuel cell, glycidyloxypropyltrimethoxysilane

(C) 2019 Penerbit UTM Press. All rights reserved

\section{INTRODUCTION}

A fuel cell as an electrochemical device has been developed to convert chemicals into electrical energy which based on the redox reactions (Ma et al., 2013). A composite polymeric membrane as a favourable proton exchanger has been widely used as the electrolyte for direct methanol fuel cells (DMFC). DMFC is capable of producing high energy with a simple design, easy handling, light in weight, environmentally-friendly and easy to move. Therefore, DMFC is commonly developed as a safe source of clean energy to be applied compared to the remaining fuel cells (Heo et al., 2012; Tohidian et al., 2013; Ting et al., 2014).

Such polymer electrolyte membranes (PEM) were mainly used in the middle between cathode and anode side. The mostly developed commercial membrane with the same function is a perflurosulfonic acid membrane $\left(\right.$ Nafion $\left.^{\odot}\right)$ due to high chemical stability and proton conductivity (Lu et al., 2013). However, the membrane has several drawbacks, such as expensive, high methanol movement, low thermal stability (up to $100{ }^{\circ} \mathrm{C}$ ), and dehydrated quickly with decreasing proton conductivity over $100{ }^{\circ} \mathrm{C}$ (Wang et al., 2010; Lufrano et al., 2013). In order to solve this problem, a novel electrolyte membrane material with a higher performance compared to the commercial material is promoted in this study.
The composite membrane consists of combined organic and inorganic materials which improved the comprehensive properties of a matrix as reported in the previous study (Yang, 2009). PEI is a polymer composed of phenyl groups, ether linkages with an imide group bonded angularly between aromatic rings in the backbone and branched chain then generate strong hydrogen bonding. The strength of the bond produces high chemical and mechanical stability, solvent and heat resistance, as well as good film-forming properties. In terms of cost effectiveness, PEI (USD $255.4 / \mathrm{kg}$ ) is much cheaper than Nafion 117 (USD 363.7 / $100 \mathrm{ml}$ ). Moreover, sulphonated PEI modification was able to increase proton conductivity up to $0.0014 \mathrm{~S} / \mathrm{cm}$ at $25^{\circ} \mathrm{C}$ and an ion exchange capacity at $0.553 \mathrm{meq} / \mathrm{g}$ as reported by Rajagopalan et al. and Guhathakurta et al. Thus, it can be expected to have good prospects as a base material of polymer matrix membrane for DMFC application. In addition, the mechanical and chemical stability can be further improved using filler addition such Nafion or polymers- $\mathrm{TiO}_{2}$ composite membranes which have attracted the attention of many researchers (Baglio et al., 2005; Chen et al., 2007; Hammami et al., 2012).

Titanium dioxide $\left(\mathrm{TiO}_{2}\right)$ is a good candidate for the hydrophilic filler because it provides suitable hydration of the membrane under fuel cell operation conditions (Hammami et al., 2012). Nafion with blended $\mathrm{TiO}_{2}$ by sol-gel method to form a composite membrane showed an improved cell performance at $130{ }^{\circ} \mathrm{C}$. In addition, GPTMS has been 
used to improve the interconnection between organic and inorganic material, due to its coupling agent characteristic (Wang et al., 2010). Therefore, the present investigation was performed to study the effect of sulfonated polyetherimide with $\mathrm{TiO}_{2}$ modification using GPTMS as a filler to enhance the performance of a novel composite electrolyte membranes which has not been reported yet.

\section{EXPERIMENTAL}

\section{Materials}

Commercially available polyetherimide (PEI) (Sigma-Aldrich) was used as SPEI membrane material as well as chlorosulfonic acid (p.a 97\%, Sigma-Aldrich) and 1,2-dichloroethane (p.a 99\%, SigmaAldrich). $\quad \mathrm{N}, \mathrm{N}$-dimethyl-acetamide (DMAc) and $\mathrm{N}$-methyl-2pyrrolidone (NMP) were supplied by Sigma-Aldrich and used as a solvent to prepare the polymeric solution. Isopropanol (Sigma-Aldrich) as a precipitating-agent. The Nafion ${ }^{\circledR} 117$ membranes was purchased from DuPont Co. $\mathrm{TiO}_{2}(\mathrm{Mw}=79,87 \mathrm{~g} / \mathrm{mol}, 21 \mathrm{~nm}$ particle size $)$ by Sigma-Aldrich. Toluene, chloride acid, sulfuric acid, and GPTMS were also purchased from Sigma Aldrich. Demineralized water was used to reduce the acidity.

\section{Preparation of Sulfonated polyetherimide (SPEI)}

Firstly, $10 \mathrm{~g}$ PEI was dissolved in $60{ }^{\circ} \mathrm{C}$ of $50 \mathrm{~mL}$ dichloroethane for $5 \mathrm{~h}$. Next, the solution was stirred at room temperature for $1 \mathrm{~h}$. Then, a mixture of $2.06 \mathrm{~mL}$ chlorosulfonic acid:35 mL dichloroethane was dropped gradually into the polymer solution under stirring for $45 \mathrm{~min}$. After $2 \mathrm{~h}$, the final solution was dissolved in DMAc and precipitated using isopropanol. The product was filtered and washed with isopropanol three times to remove the excess of acidity, and dried at 50 ${ }^{\circ} \mathrm{C}$ for $48 \mathrm{~h}$. The obtained polymer was characterized using infrared spectrophotometer as referred on the previous study (Shen et al., 2003; Guhathakurta et al., 2009; Rajagopalan et al., 2010)

\section{Preparation of GPTMS-modified $\mathrm{TiO}_{2}$}

GPTMS, $\mathrm{TiO}_{2}$, and toluene were refluxed at $110^{\circ} \mathrm{C}$ for $24 \mathrm{~h}$ with a weighted ratio of $2: 1: 20$, respectively. Then, the resulting product was washed using ethanol in three times and immersed in a $0.1 \mathrm{M} \mathrm{HCl}$ for $24 \mathrm{~h}$. It was filtered, washed with demineralized water, and dried at 100 ${ }^{\circ} \mathrm{C}$ (Wang, 2010).

\section{Fabrication of SPEI/GPTMS-TiO ${ }_{2}$ membranes}

The GPTMS addition in a different mass composition of 3,5 , and $7 \mathrm{wt} \%$ was prepared to modify in composite membrane. The SPEI polymers were dissolved in NMP, put on the GPTMS-TiO 2 , and stirred at $60{ }^{\circ} \mathrm{C}$ for $12 \mathrm{~h}$. After that, the solution was cooled down to room temperature before being cast on glass plates. The resulted membrane was then dried at room temperature for $12 \mathrm{~h}$ before being immersed in sulfuric acid for $12 \mathrm{~h}$.

\section{Characterization of SPEI/ GPTMS-TiO 2 membranes}

The fabricated membranes were dried at $80{ }^{\circ} \mathrm{C}$ for $1 \mathrm{~h}$ before examining the functional groups by using FT-IR measurement which was conducted in the range of $4000-400 \mathrm{~cm}^{-1}$. The morphological study on the membrane surface and cross-section of SPEI/GPTMS-TiO 2 were analyzed using a Zeuss field emission scanning electron microscope (SEM). The membrane was frozen and cut apart after being immersed in liquid nitrogen to obtain a cross-section membrane sample analysis. The membrane performance was then evaluated using contact angle (CA) Optima Surface Analysis System OCA (AST Products Inc. Billerica, MA). The membrane sample with dimension $5 \mathrm{~cm} \times 1.5 \mathrm{~cm}$ was placed on a glass plate and fixed with a tape. A drop of distilled water was dropped onto the sample surface using a microsyringe (Hamilton Company, Reno, NV). The CA was measured within $30 \mathrm{~s}$ period after the water was dropped. The CA value was presented as an average value from 10 different spots on the membrane sample.

The mechanical strength properties of the SPEI/GPTMS-TiO 2 membrane were measured by the tensile machine (Instron 5567, TA Instruments Co.) at room temperature. The sample was taken at a rate of $5.0 \mathrm{~mm} \mathrm{~min}{ }^{-1}$ which taken five times to obtain an average value.
Thermal stability of the SPEI/ GPTMS-TiO 2 membrane was characterized using TGA. Dry sample was ground into fine powder and the sample was placed in a platinum pan. The sample powder was prepared in the pin stub holder and coated with gold with carried out temperature between $30-900{ }^{\circ} \mathrm{C}$ using heating rate of $10{ }^{\circ} \mathrm{C} \mathrm{min}-1$ under air atmosphere.

\section{Water uptake and swelling ratio}

The SPEI/GPTMS-TiO 2 membrane was dried at $80{ }^{\circ} \mathrm{C}$ under vacuum for $24 \mathrm{~h}$. The weight and dimension of the membrane were measured before being immersed in deionized water for $24 \mathrm{~h}$ at room temperature. The membrane was then weighed to determine its weight in the wet condition. The dimension of the wet membrane was also recorded. Prior to the measurement, the moisture on the surface of the membrane was blotted dry using absorbent paper. The water uptake and swelling ratio of the membrane were determined using the following equations:

$$
\text { Water uptake }=\frac{\mathrm{W}_{\text {wet }}-\mathrm{W}_{\text {dry }}}{\mathrm{W}_{\text {dry }}} \times 100 \%
$$

where $W_{\text {wet }}$ and $W_{\text {dry }}$ are the weight of the membrane in wet and dry state, respectively (Purwanto et al., 2016).

$$
\text { Swelling ratio }=\frac{\mathrm{L}_{\mathrm{wet}}-\mathrm{L}_{\mathrm{dry}}}{\mathrm{L}_{\mathrm{dry}}} \times 100 \%
$$

where $L_{w e t}$ and $L_{d r y}$ are the length of the membrane in wet and dry condition, respectively (Liu et al., 2014).

\section{lon exchange capacity (IEC)}

The IEC of the SPEI/GPTMS-TiO 2 membrane was obtained using titration method. The membrane was dried at $50{ }^{\circ} \mathrm{C}$ for $24 \mathrm{~h}$, and weighed. Then the membrane was soaked in $50 \mathrm{~mL}$ of $1 \mathrm{M} \mathrm{NaCl}$ solution to exchange the $\mathrm{H}^{+}$ions in the membrane matrix with $\mathrm{Na}^{+}$. The solution was titrated with $0.01 \mathrm{M} \mathrm{NaOH}$. $1 \mathrm{wt} \%$ phenolphthalein in ethanol solution was used as an indicator. The IEC of the membrane was calculated using the following equation:

$$
\text { IEC }(\mathrm{mmol} / \mathrm{g})=\frac{\mathrm{MNaOH} \times 1000 \times \mathrm{VNaOH}}{W d}
$$

where $\mathrm{V}_{\mathrm{NaOH}}$ is the $\mathrm{NaOH}$ consumed solution, $\mathrm{M}_{\mathrm{NaOH}}$ is the concentration of $\mathrm{NaOH}$, and $\mathrm{W}_{\mathrm{d}}$ is the weight of the dry membrane (Purwanto et al., 2016).

\section{Methanol permeability and proton conductivity}

Methanol permeability was determined using a two-compartment diffusion cell. Compartment A was filled with $1 \mathrm{M}$ methanol solution and compartment $\mathrm{B}$ was filled with deionized water. The membrane was placed between compartment A and B. Samples from compartment B were taken out every 30 minutes for 6 hours to determine the methanol concentration using high-performance liquid chromatography (HPLC). The methanol permeability values were determined by using equation (4).

$$
\mathrm{P}=\left(\frac{\Delta \mathrm{C}_{\mathrm{B}}}{\Delta \mathrm{t}}\right)\left(\frac{\mathrm{LV}_{\mathrm{B}}}{\mathrm{AC} \mathrm{C}_{\mathrm{A}}}\right)
$$

Based on Equation 4, $P$ is methanol permeability of the membrane $\left(\mathrm{cm}^{2} \cdot \mathrm{s}^{-1}\right), \Delta C_{B} / \Delta t$ is the slope variation of methanol concentration in compartment $\mathrm{B}$ as a function of time $\left(\mathrm{mol} \mathrm{L}^{-1} \cdot \mathrm{s}^{-1}\right), L$ is the thickness of the membrane $(\mathrm{cm}), V_{B}$ is the volume of the water at compartment $\mathrm{A}$ $\left(\mathrm{cm}^{3}\right), A$ is the membrane surface area $\left(\mathrm{cm}^{2}\right)$, and $C_{A}$ is the concentration of methanol in the cell A $\left(\mathrm{mol} \mathrm{L}^{-1}\right)$ (Purwanto et al., 2016).

The proton conductivity of the SPEI/ GPTMS-TiO 2 membrane was measured using electrochemical impedance spectroscopy (EIS) over a frequency range of $1-10^{6} \mathrm{~Hz}$. The proton conductivity values were calculated using equation (5):

$$
\sigma=\frac{\mathrm{L}}{\mathrm{R} \times \mathrm{A}}
$$


where $\sigma$ is the proton conductivity of the membrane $\left(\mathrm{S} \mathrm{cm}^{-1}\right), L$ is the membrane $(\mathrm{cm}), A$ is the membrane surface area $\left(\mathrm{cm}^{2}\right)$, and $R$ is the membrane resistance $(\Omega)$ (Purwanto et al., 2016).

\section{RESULTS AND DISCUSSION}

\section{Morphological analysis}

Figure 1 shows the SEM image of different morphological structure of PEI-based polymeric membrane. According to the previous work by Muliawati et al. (2017a), Figure 1a shows SPEI-based membrane with dense structure and some defects at the surface while Figure $1 \mathrm{~b}$ illustrates the remains of $\mathrm{TiO}_{2}$ agglomeration (spherical bulk) on the surface, indicating low $\mathrm{TiO}_{2}$ particle distribution and interconnection bonding between $\mathrm{TiO}_{2}$ as inorganic material with SPEI as organic compound. In this work, the tight bonding between $\mathrm{TiO}_{2}$ and SPEI was successfully modified by GPTMS addition as shown in Figure 1c. The red arrow shows the GPTMS as connecting fiber which leads to the interconnection of those SPEI and $\mathrm{TiO}_{2}$. This means that the interconnection can improve the mechanical and proton conductivity properties as referred to Wang et al. (2010) using Chitosan/GPTMSzeolite $\beta$ membrane.
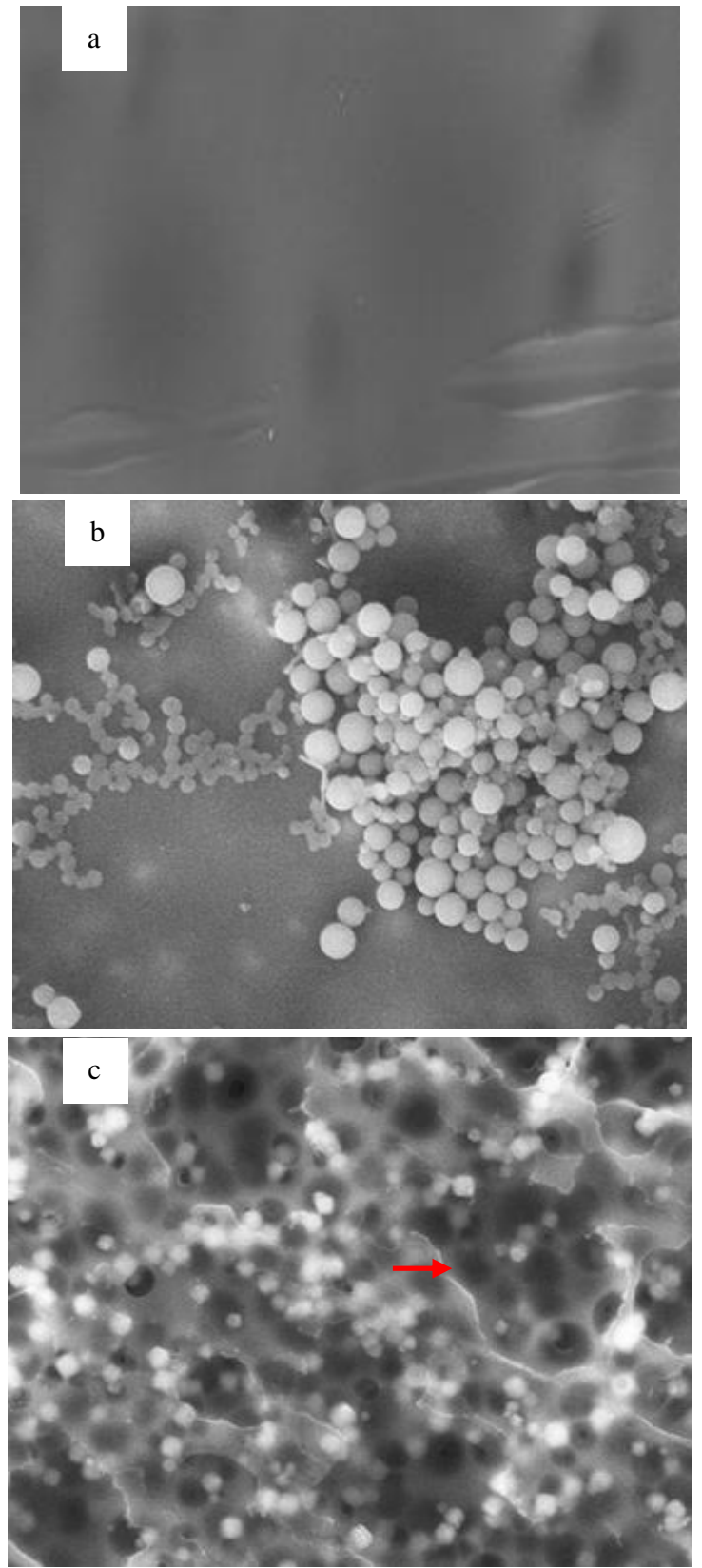

Figure 1 SEM image of (a) SPEI membrane (Muliawati et al., 2017), (b) $\mathrm{SPEI} / \mathrm{TiO}_{2}$ membrane and (c) SPEI / GPTMS-TiO

\section{FT-IR measurement}

To gather more information about the presence of SPEI/GPTMS$\mathrm{TiO}_{2}$ interconnections, the membranes were characterized by FT-IR as shown in Figure 2. Figure 2a shows SPEI membrane spectra while Figure $2 \mathrm{~b}$ shows SPEI spectra after GPTMS- $\mathrm{TiO}_{2}$ addition at various ratio i.e. $3 \%-5 \%, 5 \%-5 \%$, and $7 \%-5 \%$. The results showed that the broadening absorption peak on both spectra at around $3600 \mathrm{~cm}^{-1}$ assigned a vibration of $-\mathrm{OH}$ from the interaction between $-\mathrm{SO}_{3} \mathrm{H}$ and $\mathrm{H}_{2} \mathrm{O}$ molecules (Rajagopalan et al., 2010; Liu et al., 2014; Muliawati et al., 2017a). The absorption spectra at around $3000-2800 \mathrm{~cm}^{-1}$ reveal to $\mathrm{Csp}_{3}-\mathrm{H}$ span and the methylene absorption band at $1400 \mathrm{~cm}^{-1}$ as well as $-\mathrm{CN}$ absorption band at $1460 \mathrm{~cm}^{-1}$. In addition, the $\mathrm{S}=\mathrm{O}$ absorption from $-\mathrm{SO}_{3} \mathrm{H}$ functional group was shown at around 1279 and $1071 \mathrm{~cm}^{-}$

${ }^{1}$. Furthermore, on the SPEI/GPTMS-TiO 2 spectra showed a sharp peak at around 400-700 and $995 \mathrm{~cm}^{-1}$ (Ti-O,Ti-O-Ti and Ti-O-Si) which indicated the presence of GPTMS and $\mathrm{TiO}_{2}$. This FTIR result indicates that the modification of GPTMS- $\mathrm{TiO}_{2}$ has been successfully interconnected in SPEI as accordance to the SEM result.

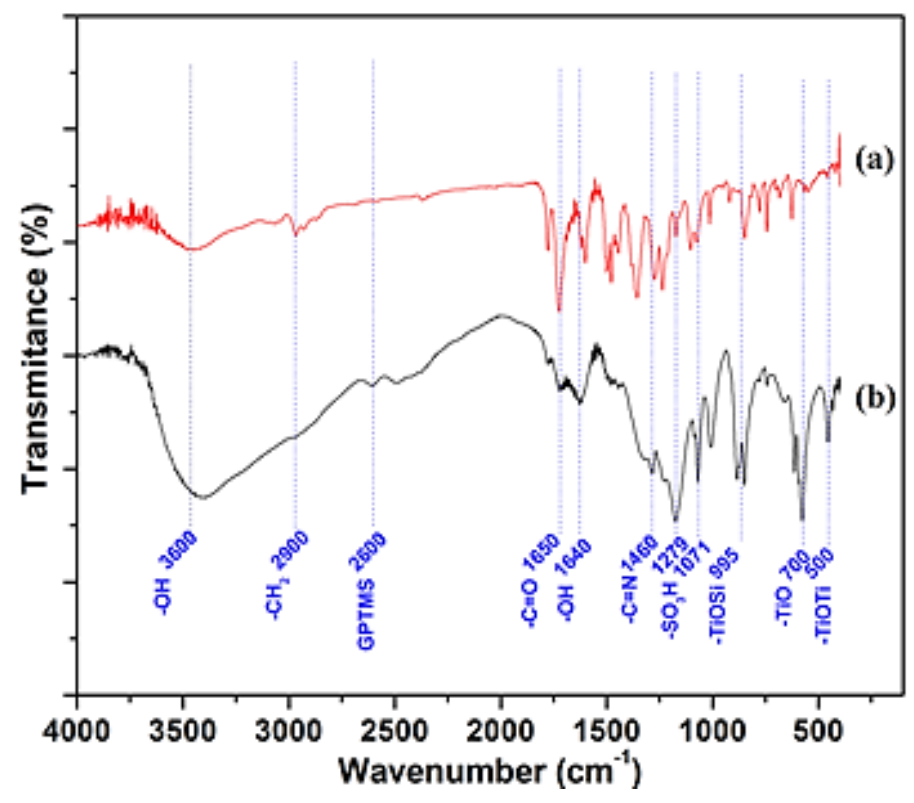

Figure 2 FT-IR spectra of (a) SPEI and (b) SPEI/GPTMS-TiO 2.

\section{Mechanical and thermal stability properties}

PEM with good mechanical properties is required to improve the performance in terms of the membrane flexibility for DMFC application. As can be seen in Figure 3, the mechanical properties of the SPEI / GPTMS-TiO 2 membrane shows higher tensile strength as compared to the SPEI membrane. The tensile strength of the SPEI membrane showed higher value than $3 \%$ GPTMS-5\% $\mathrm{TiO}_{2}$ addition because $3 \%$ GPTMS was not enough to be used to form SPEI and $\mathrm{TiO}_{2}$ interconnection. The less crosslinking formation reduced the molecular flexibility and became less elongated before the membrane was damaged. While the increasing GPTMS addition from $3 \%$ to $7 \%$ showed increasing tensile strength from 15.8 to $22.0 \mathrm{MPa}$.

Moreover, the resulting mechanical properties measurement also showed that the increasing filler addition increased the mechanical properties up to $3 \%$ addition of GPTMS then significantly constant at $5 \%$ and $7 \%$ GPTMS addition of 21.1 and $22 \mathrm{MPa}$, respectively. This is due to GPTMS-TiO 2 perfectly interact with SPEI monomer to form macromolecules of SPEI/GPTMS- $\mathrm{TiO}_{2}$ at $3 \%$ GPTMS composition. It indicated that the crosslinking between filler and polymer was perfectly connected to form the SPEI/GPTMS-TiO2 interconnection. The illustration of the interaction between GPTMS-TiO 2 and SPEI monomer is clearly revealed in Figure 4 which also shows the probability of proton transport mechanism. The proton from methanol and/or water passes the membrane through the $-\mathrm{OH}$ and $-\mathrm{SO}_{3} \mathrm{H}$ groups then the proton initiated the electric current production on DMFC application as reported by Purwanto et al. (2016). 


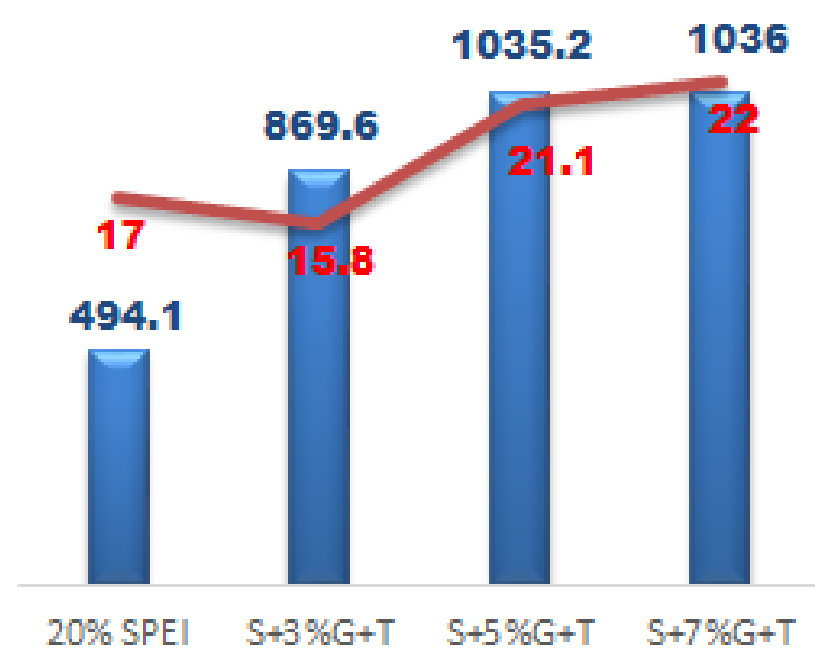

Young Modulus —Tensile strength

Figure 3 The mechanical properties of SPEI/GPTMS-TiO .

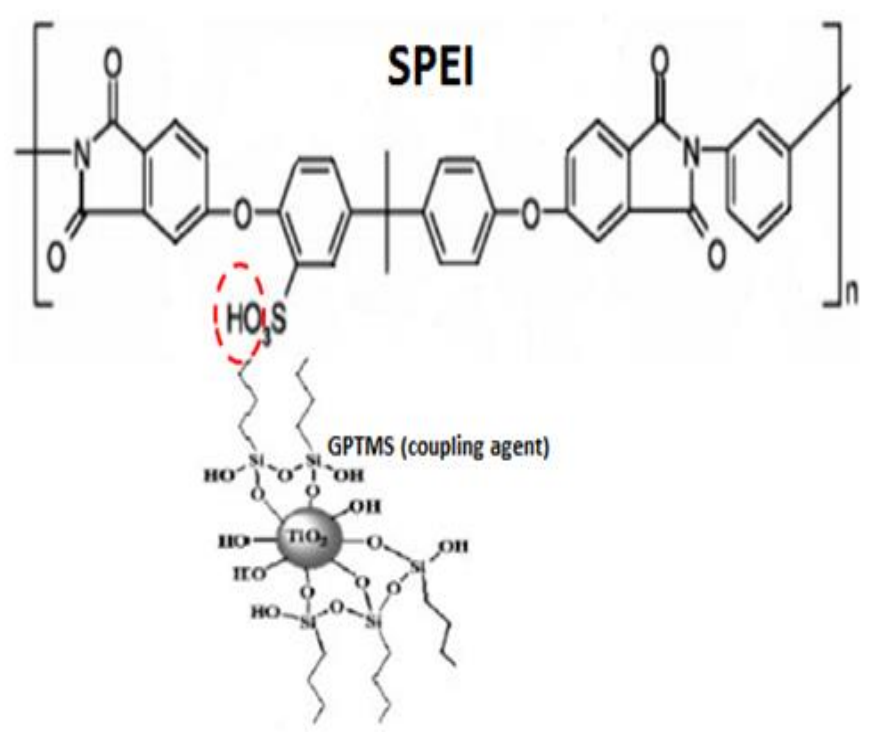

Figure 4 The illustration of proton transport mechanism on the

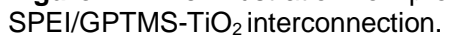

In addition, TGA was also applied to measure the membrane thermal stability and a cross-linking formation, respectively. It can be seen in Figure 5, the TGA measurement of SPEI/5\%GPTMS-5\% $\mathrm{TiO}_{2}$ shows a difference in temperature weight loss compared to the SPEI membrane. However, the stability of the two membranes was still above $80{ }^{\circ} \mathrm{C}$, indicating that the membrane thermal stability was good enough for the desired DMFC application conditions. The weight lost at around $100{ }^{\circ} \mathrm{C}$ and $250{ }^{\circ} \mathrm{C}$ in SPEI/GPTMS-TiO 2 membrane indicate the decomposition of hidroxyde and sulfonic acid groups in the polymer chain (Rajagopalan et al., 2010). The few percentage of weight lost at above $100^{\circ} \mathrm{C}$ described the sufficient thermal stability of the membrane for required DMFC application conditions.

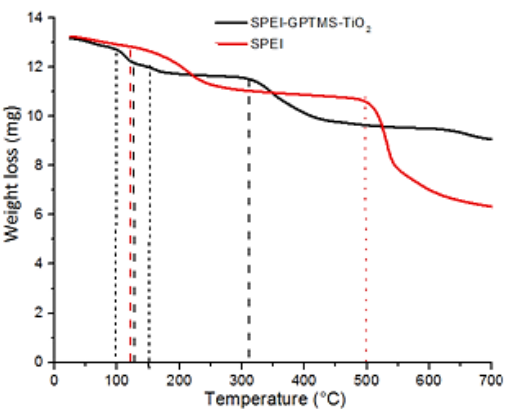

Figure 5 The thermal stability (TGA) of the SPEI (Muliawati et al., 2017a) and SPEI/GPTMS-TiO2.

\section{Perfomance Test of SPEI/GPTMS-TiO 2 membrane}

The membrane has been measured the membrane capacity, methanol permeability, and proton conductivity as reported in Table 1 and Table 2, respectively. The SPEI/GPTMS-TiO 2 membrane with 5 wt $\%$ GPTMS showed the highest performance as it possessed the desired properties to be applied for DMFC application where the parameters were the water uptake, methanol uptake, membrane swelling ratio, ion exchange capacity (IEC), water contact angle, proton conductivity, and methanol permeability measurement. Water and methanol uptakes attributes to the ion and methanol diffusion through the electrolyte membrane. The swelling ratio indicates the stability of the membrane in an aqueous solution (Wang et al., 2009) and ion exchange capacity (IEC) is defined as fixed group millionaires of exchange per gram of polymer, usually corresponding to the number of sites for proton transfer (Yang, 2009). The contact angle reveals the hydrophilic or hydrophobic degree of a material. The conductivity of protons is one of the most important factors for proton membranes used in fuel cells. In general, proton transport in a hydrated polymer matrix is described by two main mechanisms: proton hopping or the Grotthus mechanism using a "diffusion mechanism" using water (-OH groups) as proton transport or "vehicular mechanism" (Purwanto et al., 2016). Methanol permeability is measured to evaluate the membrane ability to prevent the methanol crossover or methanol rate through the membrane structure (Liu et al., 2014). All of these parameters are interlinked for good performance in DMFC applications.

Well-performing membranes generally have high proton conductivity with high water uptake, low methanol absorption and permeability of methanol, high ionic exchange capacity (IEC), low membrane swelling ratio, lower contact angle (membrane more likely to be hydrophilic), as well as can be operated at high temperatures (> $80^{\circ} \mathrm{C}$ ). Water uptake contributes substantially to the formation of hydrophilic properties in membranes capable of facilitating proton transport even under low humidity conditions (Shu et al., 2008). The water absorption rate in the polymer can be increased by increasing the ionic group content $\left(-\mathrm{OH}\right.$ and $\left.-\mathrm{SO}_{3} \mathrm{H}\right)$ in the polymer chain, but too much water uptake leads to an increase in swelling of the membrane, resulting in loss of mechanical stability in the membrane (brittle) and methanol permeability become high (Shu et al., 2008).

IEC values depend on the number of sulfonic acid groups in the chemical structure of the polymer membrane and may affect the water absorption and the conduction properties of protons on the polymer membrane (Liu et al., 2014). The value of IEC is increased when the polymer composition loading is increased (Purwanto et al., 2016). Therefore, all parameters must be optimized for further enhancing the performance of fuel cell operations. 
Table 1 The membrane properties.

\begin{tabular}{|c|c|c|c|c|c|c|}
\hline Membrane & $\begin{array}{l}\text { Water } \\
\text { uptake } \\
\text { (\%wt) }\end{array}$ & $\begin{array}{l}\text { Methanol } \\
\text { uptake } \\
\text { (\%wt) }\end{array}$ & $\begin{array}{l}\text { Swelling ratio } \\
(\%)\end{array}$ & $\begin{array}{l}\text { IEC } \\
(\mathrm{mmol} / \mathrm{g})\end{array}$ & $\begin{array}{l}\text { Contact } \\
\text { Angle } \\
\left({ }^{\circ}\right)\end{array}$ & Ref \\
\hline $20 \% \mathrm{PEI}$ & 6.1 & 5 & 4 & 0.4 & 89 & \multirow{5}{*}{$\begin{array}{l}\text { (Muliawati et } \\
\text { al., 2017)a,b }\end{array}$} \\
\hline $20 \%$ SPEI & 23.5 & 18 & 14.7 & 1.24 & 78 & \\
\hline $20 \%$ SPEI $-3 \% \mathrm{TiO}_{2}$ & 49.3 & 30 & 12 & 1.9 & 68.97 & \\
\hline $20 \%$ SPEI - $5 \% \mathrm{TiO}_{2}$ & 47.2 & 29 & 10 & 2.1 & 66.36 & \\
\hline $20 \%$ SPEI - 7\% $\mathrm{TiO}_{2}$ & 39 & 28 & 9 & 2.0 & 66.23 & \\
\hline $20 \%$ SPEI - 3\% GPTMS - 5\% $\mathrm{TiO}_{2}$ & 54 & 33 & 11 & 2.4 & 71.11 & \multirow{4}{*}{$\begin{array}{l}\text { This work } \\
\text { This work } \\
\text { This work } \\
\text { (Liu et al., } \\
\text { 2014) }\end{array}$} \\
\hline $20 \%$ SPEI - 5\%GPTMS - 5\% $\mathrm{TiO}_{2}$ & 53 & 32 & 11.5 & 2.5 & 69.66 & \\
\hline $20 \%$ SPEI - 7\%GPTMS - 5\% $\mathrm{TiO}_{2}$ & 52 & 30.9 & 12 & 2.6 & 63.81 & \\
\hline Nafion $^{\circledR} 117$ & 19.3 & 41 & 16.4 & 0.98 & 80 & \\
\hline
\end{tabular}

Table 2 The methanol permeability and proton conductivity of membranes.

\begin{tabular}{|c|c|c|c|}
\hline Membrane & $\begin{array}{l}\text { Proton Conductivity } \\
\left(\mathrm{S} . \mathrm{cm}^{-1}\right)\end{array}$ & $\begin{array}{l}\text { Methanol Permeability } \\
\left(\times 10^{-7} \mathrm{~cm}^{2} \cdot \mathrm{s}^{-1}\right)\end{array}$ & Ref \\
\hline $20 \%$ SPEI & 0.0078 & 10 & \\
\hline $20 \% \mathrm{SPEI}-3 \% \mathrm{TiO}_{2}$ & 0.000178 & 11 & (Muliawati et al., \\
\hline $20 \%$ SPEI $-5 \% \mathrm{TiO}_{2}$ & 0.000180 & 17 & 2017)a,b \\
\hline $20 \%$ SPEI $-7 \% \mathrm{TiO}_{2}$ & 0.000181 & 19 & \\
\hline $20 \%$ SPEI - 3\% GPTMS - 5\% $\mathrm{TiO}_{2}$ & 0.000226 & 7.6 & This work \\
\hline $20 \%$ SPEI - 5\%GPTMS - $5 \% \mathrm{TiO}_{2}$ & 0.000216 & 8.7 & This work \\
\hline $20 \%$ SPEI - 7\%GPTMS - 5\% $\mathrm{TiO}_{2}$ & 0.000207 & 10.8 & This work \\
\hline Nafion $^{\circledR} 117$ & 0.090 & 25 & (Liu et al., 2014) \\
\hline
\end{tabular}

\section{CONCLUSION}

It can be concluded that the SPEI/GPTMS-TiO 2 membrane with $20 \mathrm{wt} \%$ SPEI and 5wt $\%$ GPTMS- $\mathrm{TiO}_{2} 5 \mathrm{wt} \%$ composition showed high performance which can be applied on direct methanol fuel cell membrane due to the low methanol permeability compared to commercial membrane Nafion. Additionally, it also has a hightemperature stability at above $100{ }^{\circ} \mathrm{C}$. Although proton conductivity was quite low, it can be modified with other polymers or fillers to improve its properties. Given the presence of $-\mathrm{OH}$ and $-\mathrm{SO}_{3} \mathrm{H}$ functional groups on the SPEI/GPTMS- $\mathrm{TiO}_{2}$ membrane, this resulted in the possibility of proton transport through the membrane.

\section{ACKNOWLEDGEMENT}

The authors would like to acknowledge the Indonesian Ministry of Research and Higher Education for providing scholarship and pursuing Doctoral Degree for Eka Cahya Mulyawati in the Department of Chemistry, Institut Teknologi Sepuluh Nopember and financial support under research grant "Penelitian Disertasi Doktor" number 1444/E3/LT/2017. The authors also would like to express gratitude to the Ministry of Science, Technology and Innovation (MOSTI) Malaysia and Ministry of Higher Education for the financial support from the grants with the vote number of R.J130000.7942.4S507, R.J130000.7809.4F592 and Q.J130000.2509.05H52, and also to the research management centre (RMC), Universiti Teknologi Malaysia for supporting the research management activities.

\section{REFERENCES}

Baglio, V., Aric ‘o, A. S., Blasi, A. D., Antonucci, V., Antonucci, P. L., Licoccia, S. 2005. Nafion- $\mathrm{TiO}_{2}$ composite DMFC membranes: Physico-chemical properties of the filler versus electrochemical performance. Journal of Electrochimica Acta, 50,124, 1- 6.

Chen, S. Y, Han, C. C., Tsai, C. H., Huang, J., Chen, Y. W. 2007. Effect of morphological properties of ionic liquidtemplated mesoporous anatase $\mathrm{TiO}_{2}$ on performance of PEMFC with $\mathrm{Nafion} / \mathrm{TiO}_{2}$ composite membrane at elevated temperature and low relative humidity. Journal of Power Sources, $171,363-76$.

Guhathakurta, S., Min, K. 2009. Influence of crystal morphology of 1H-1, 2, 4triazole on anhydrous state proton conductivity of sulfonated bisphenol A polyetherimide based polyelectrolytes. Polymer, 50(4), 1034-1045.
Hammami R., Ahamed, Z., Charradi, K., Beji, Z., Ben Assaker, I., Ben Naceur, J., Auvity, B., Squadrito, G., Chtourou, R. 2012. Hybrid polymer electrolytes Nafion- $\mathrm{TiO}_{2}$ for PEMFCs: Synthesis and characterization. VIème Congrès International sur les Energies Renouvelables et l'Environnement, 1-6.

Heo, Y., Sungjin Yun, Hyungu Im, Jooheon Kim. 2012. Low methanol permeable sulfonated poly(ether imide)/sulfonated multiwalled carbon nanotube membrane for direct methanol fuel cell. Journal of Applied Polymer Science, 00, 1- 11.

Liu, S., Wang, L., Ding, Y., Liu, B., Han, X., Song, Y. 2014. Novel sulfonated poly (ether ether keton)/polyetherimide acid-base blend membranes for vanadium redox flow battery applications. Electrochimica Acta, 130, 90-96.

Lu, J. L., Qing Hong Fang, Sheng Li Li, San Ping Jiang. 2013. A novel phosphotungstic acid impregnated meso-Nafion multilayer membrane for proton exchange membrane fuel cells. Journal of Membrane Science, 427, 101-107.

Lufrano, F., Baglio, V., Staiti, P., Antonucci, V., Arico, A. S. 2013. Performance analysis of polymer electrolyte membranes for direct methanol fuel cells. Journal of Power Sources, 243, 519-534.

Ma, J., Yogeshwar Sahai. 2013. Chitosan biopolymer for fuel cell applications. Carbohydrate Polymers. 92, 955-975.

Muliawati, E. C., Santoso, M., Ismail, A. F., Jaafar, J., Salleh, M. T., Nurherdiana, S. D., Widiastuti, N. 2017. Poly(eugenol sulfonate)sulfonated polyetherimide new blends membrane promising for direct methanol fuel cell. Malaysian Journal of Analytical Sciences, 21(3), $659-$ 668.

Muliawati, E. C., Santoso, M., Ismail, A. F., Jaafar, J., Widiastuti, N. 2017. Poly(eugenol sulfonate)-sulfonated polyetherimide - Titanium Dioxide $\left(\mathrm{TiO}_{2}\right)$ new blends membrane promising for direct methanol fuel cell. Proceeding of The $7^{\text {th }}$ Anual Basic Science International Conference, ISSN 2338-0128 (3), 36-39. 7-8 March, Indonesia.

Purwanto, M., Atmaja, L., Mohamed, M. A., Salleh, M. T., Jaafar, J., Ismail, A. F., Widiastuti, N. 2016. Biopolymer-based electrolyte membranes from chitosan incorporated with montmorillonite-crosslinked GPTMS for direct methanol fuel cells. RSC Advances, 6(3), 2314-2322.

Rajagopalan M., Jin-Han, J., II-Kwon, O. 2010. Electric-stimuli-responsive bending actuator based on sulfonated polyetherimide. Sensors and Actuators B, 151, 198-204.

Santiago E. I., Isidoro, R. A., Dresch, M. A., Matos, B. R., Linardi, M., Fonseca, F.C. 2009. Nafion- $\mathrm{TiO}_{2}$ hybrid electrolytes for stable operation of PEM fuel cells at high temperature. Journal Electrochimica Acta, 54, 41117.

Shen, L. Q., Xu, Z. K., Liu, Z. M., Xu, Y. Y. 2003. Ultrafiltration hollow fiber membranes of sulfonated polyetherimide/polyetherimide blends: Preparation, morphologies and anti-fouling properties. Journal of Membrane Science, 218(1), 279-293.

Shu, Y. C., Chuang, F. S., Tsen, W. C., Chow, J. D., Gong, C., Wen, S. 2008. Journal of Applied Polymer Science, 108(3), 1783-1791. 
Tohidian, M., Seyed, R. G., Seyed E. S., Erfan, D., Mohammad, M. H-S. 2013. Organically modified montmorillonite and chitosan phosphotungstic acid complex nanocomposites as high performance membranes for fuel cell applications. Journal of Solid State Electrochemistry, 17, 2123-2137.

Ting, Y., Longjuan, Pu, Qinghong, H., Haifeng, Z., Xuemei, L., Hui, Y. 2014 An effective methanol-blocking membrane modified with graphene oxide nanosheets for passive direct methanol fuel cells. Electrochimica Acta, 117, $393-397$.

Vaghari, H., Hoda, J-M., Aydin, B., Navideh, A. 2013.Recent advances in application of chitosan in fuel cells. Sustainable Chemical Processes, 1-16.
Wang, Y., Goh, S. H., Chung, T. S., Na, P. 2009. Journal of Membrane Science, 326(1), 222-233.

Wang, Y., Jiang, Z., Li, H., Yang, D. 2010. Chitosan membranes filled by GPTMS modified zeolite beta particles with low methanol permeability for DMFC. Chemical Engineering and Processing, 49, 278-285.

Yang, T. 2009. Composite membrane of sulfonated poly (ether ether ketone) and sulfated poly (vinyl alcohol) for use in direct methanol fuel cells. Journal of Membrane Science, 342(1), 221-226. 